\title{
A building in Bloomsbury: drawing BMA House
}

\author{
DAVID GENTLEMAN
}

Bloomsbury is a district of handsome tree filled squares and elegant terraces, now mostly turned into offices but still retaining the pleasant human quality that clings to buildings that once were houses. Tucked in among these are, of course, many newer buildings, unlikely to be thought of as part of the typical Bloomsbury and easy to ignore unless one has a particular reason to look at or to visit them. BMA House is one of the biggest of these; but the casual passer by would hardly suspect this, since one never sees it whole. Its two public facades, the western on Southampton Row and the eastern on Burton Street, are so far apart that they seem unconnected, hardly part of the same building; and indeed they are by different architects. Sir Edwin Lutyens designed the core of it but the front range is by Cyril Wontner Smith and Douglas Wood.

Early this year I began work on a commission from the Editor to paint a watercolour of BMA House to appear on the cover of the BMY's anniversary issue and to make a lithograph of the building: an interesting assignment but not a simple one. Drawing or painting a building with many possible viewpoints is never plain sailing. Where does one begin? An aspect that may have enough appeal for a quick sketch may not hold one's interest for long, and in selecting a pretty detail one may neglect a more important aspect which everyone knows well. On the other hand, the most familiar is not necessarily the most interesting.

\section{Inside and outside}

The facade on Southampton Row is in red brick, grey-blue slate, and white Portland stone, not unlike the American colonial style buildings in Grosvenor Square. The brick halfcolumns reminded me of brick pillars I once saw on a colonial period church in South Carolina. But that was a small, intimate building, whereas the three-storey columns on BMA House are cold and monumental: the domestic flavour of red brick does not quite go with the six storeys that rise here. But, entering the building through the central arches, past the amiably vigilant porter in his office on the left, one senses a change of scale and of style as one passes through a wrought iron screen into Lutyens's domain. Its central open air feature is the main courtyard, where a grand pedimented facade looks down on to a group of 1930ish stone figures standing round a fountain. The

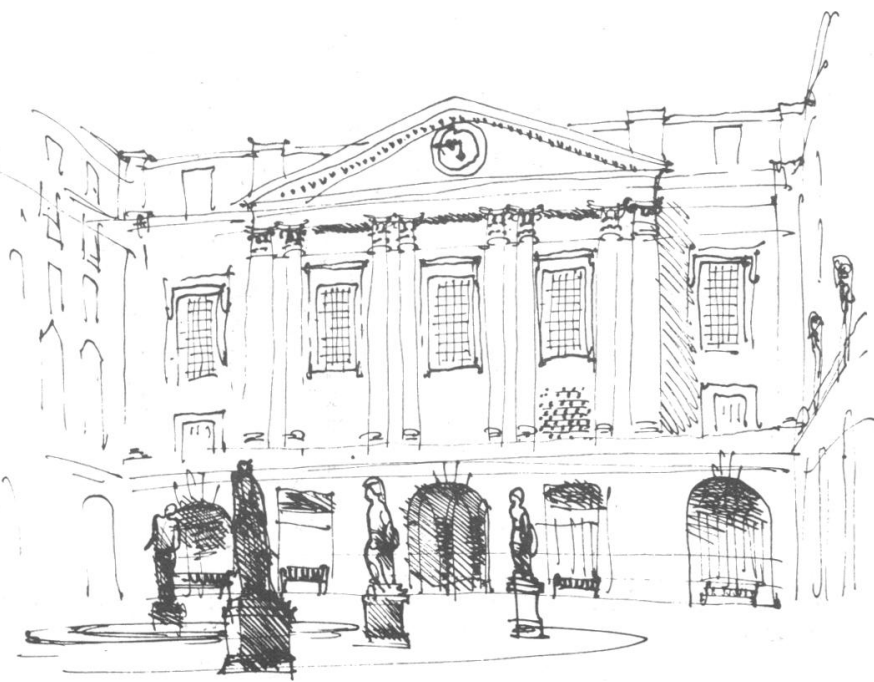

arches beneath the pediment lead to the spacious dining room and members' room and to the staircases leading up to pleasant but unremarkable passages, corridors, offices, committee rooms, and finally to Lutyens's Great Hall.

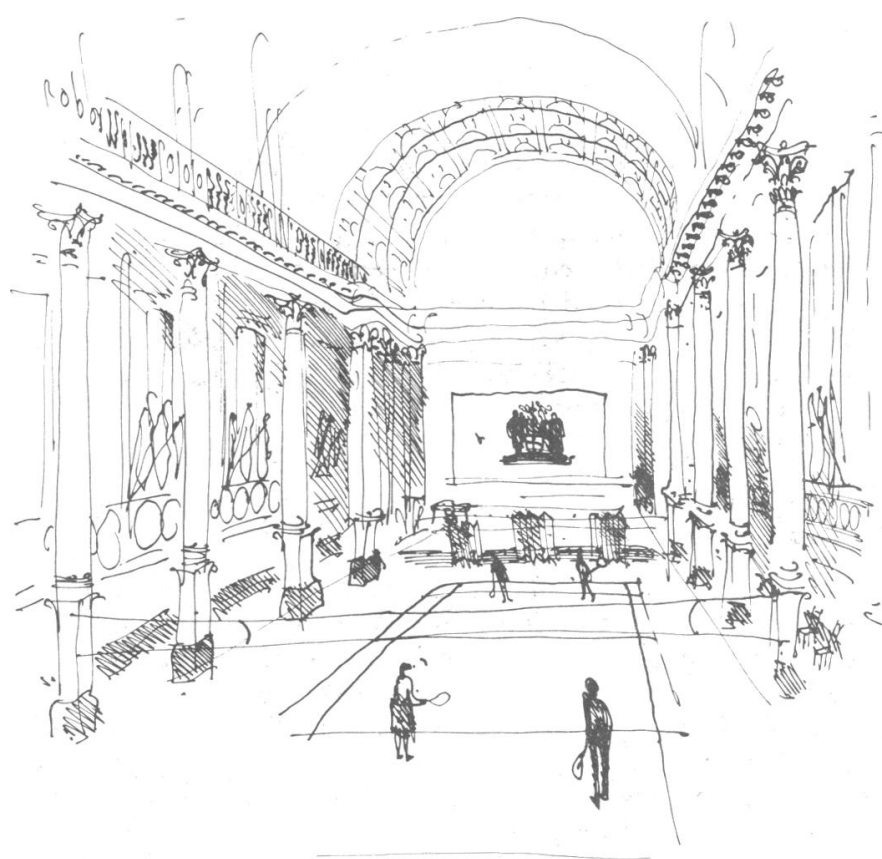

This is quite the most ambitious feature of the whole building -a vast space whose coffered and partly unfinished roof is carried on fine pillars, with a stage at the north end, a gallery at the south, and daylit aisles on either side. It is formal and monumental in conception; yet it doubles happily as a sort of grand gym, where you can play badminton beneath the gilded columns and the banners, as if it were a great school hall. Lutyens seems at full power here; this is the bit he must have most enjoyed doing. It would have made a good subject for anyone who likes drawing interiors; but I prefer tackling exteriors, where the changing light and the presence of foliage add interest and variety. They also prevent one feeling that one is merely recording something that is already a work of art in its own right. So I had a look at the hall from the outside. Lutyens's capable hand again shows clearly in the majestic seven-bay range of windows; here there is less stone than at the front, as the brickwork comes right down to ground level and stone is restricted to string courses and to emphatic arches over the lower windows.

But, although this is impressive as architecture, it does not at present make a very attractive pictorial composition, being flanked by a wired off parking lot: one could make a picture of it only by shutting one's eyes to the immediate surroundings. So I turned back again to explore the interior in search of a more satisfactory subject. And indeed there is a very picturesque one

Camden, London

DAVID GENTLEMAN, artist and author 


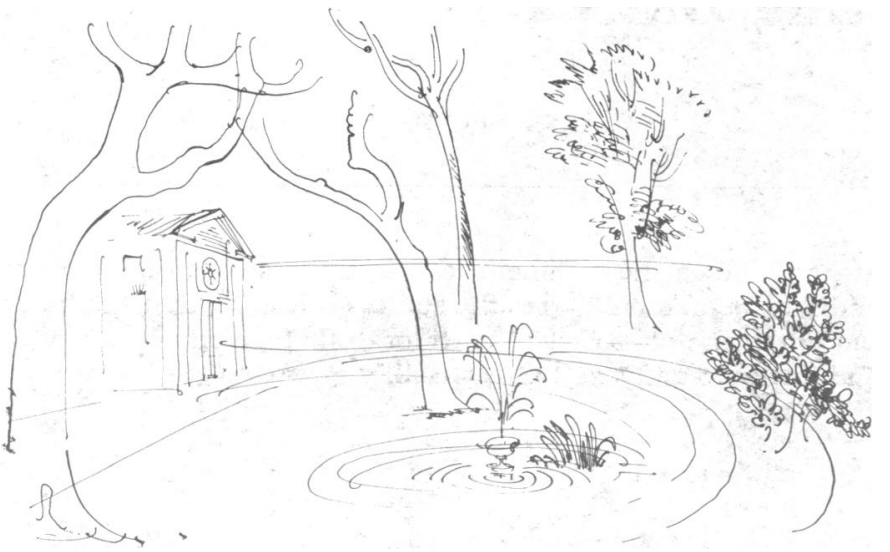

in the charming small courtyard south of the main one, where another fountain splashes into a small pond and old trees shelter one from the severity of the neo-Georgian walls above. It is a pretty and secluded scene, which seems far removed from the London pavements which surround it. Yet it is hardly familiar - many visitors never see it. So eventually I returned to the Tavistock Square facade, certain that this was where the subject would eventually be found.

\section{Out in the square}

Yet even now all was not quite resolved. BMA House hardly hits you in the eye. Coming in a bus down Southampton Row you might well miss it, seeing it only obliquely and then with your eyes half seduced by the greenery of the Square opposite; and it was the view through these trees that first took my fancy. Tall and splendid planes line the square, and in early spring one can get a good view of the red brick BMA facade between their trunks-a view enlivened by the animation of the lawns and paths, the commuters, loungers, gardeners, tramps, and a steady stream of talkative London visitors. But soon the advancing season obscures the view, as the planes and the smaller blossoming trees beneath them burst into leaf. And, in any case, I prefer to draw a facade from head on rather than slightly at a slant. So my first more careful study was made from the pavement just outside the square's railings, where one sees the building full frontal and half framed by tree trunks, branches, foreground shrubbery, and parking meters.

This composition had its points. It was clearly the right subject. But it also had its drawbacks. It was very much a straightforward portrait of a facade in very good condition, unrelieved by the pleasant accidental effects of weathering and perhaps hardly interesting enough architecturally or graphically to sustain such a bald head-on scrutiny. It did not even have the excuse of paying homage to Lutyens. And the railings on the right were rather dull replacements of the old cast-iron ones melted down for munitions during the war: not really interesting enough for it to be a pleasure to draw them. What has been dull to draw is sure to be duller still to look at. And yet, wandering about in and around the square, I still felt that the building and the beautiful trees would surely make a good subject if only I could see it.

Not quite all of the old cast-iron railings had disappeared. On the west side of the square they still stand to protect the entrance to the corner house now occupied by the Committee of Vice Chancellors and Principals. Standing rather gingerly on the steps up to this august front door, I suddenly saw what I needed: a picture, not simply of a building facade but of a Bloomsbury square with its trees and pavements and as its foreground the elegant railings which-as in Bath-extend the orderliness and grace of the buildings out on to the pavement.

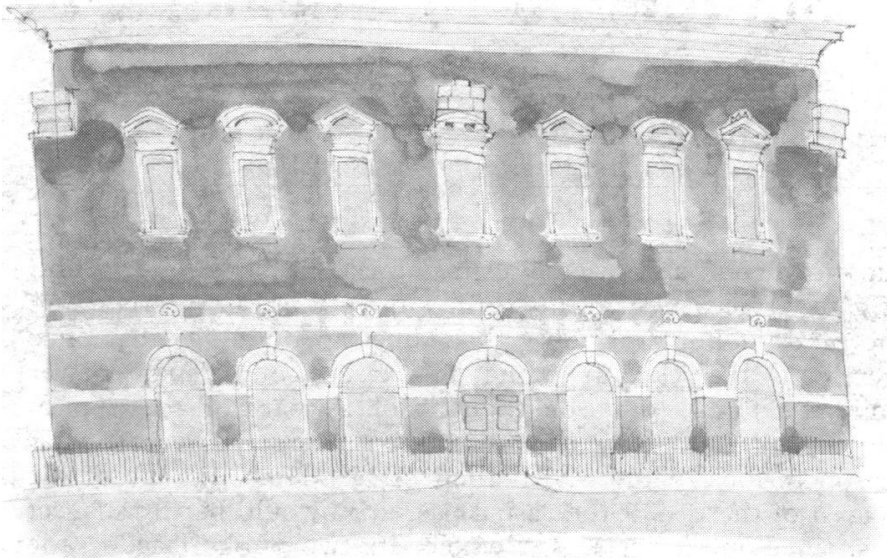

In the distance was just enough of BMA House, its structure and symmetry clearly visible through the thickening leaves but its more repetitive elements-brick columns, corinthian capitals, the grid of neo-Georgian windows-half hidden by the screen of branches and foliage dropping in front of it. This instantly seemed to me the most promising composition, and it was the one I finally made into the lithograph.

It was a pleasant task to draw the studies on the spot in the first warm days of spring. The big zinc plates of the lithograph were proofed and printed by the craftsman printers at the Curwen Studio in Midford Place just off Tottenham Court Road, only a few minutes' walk away from the subject.

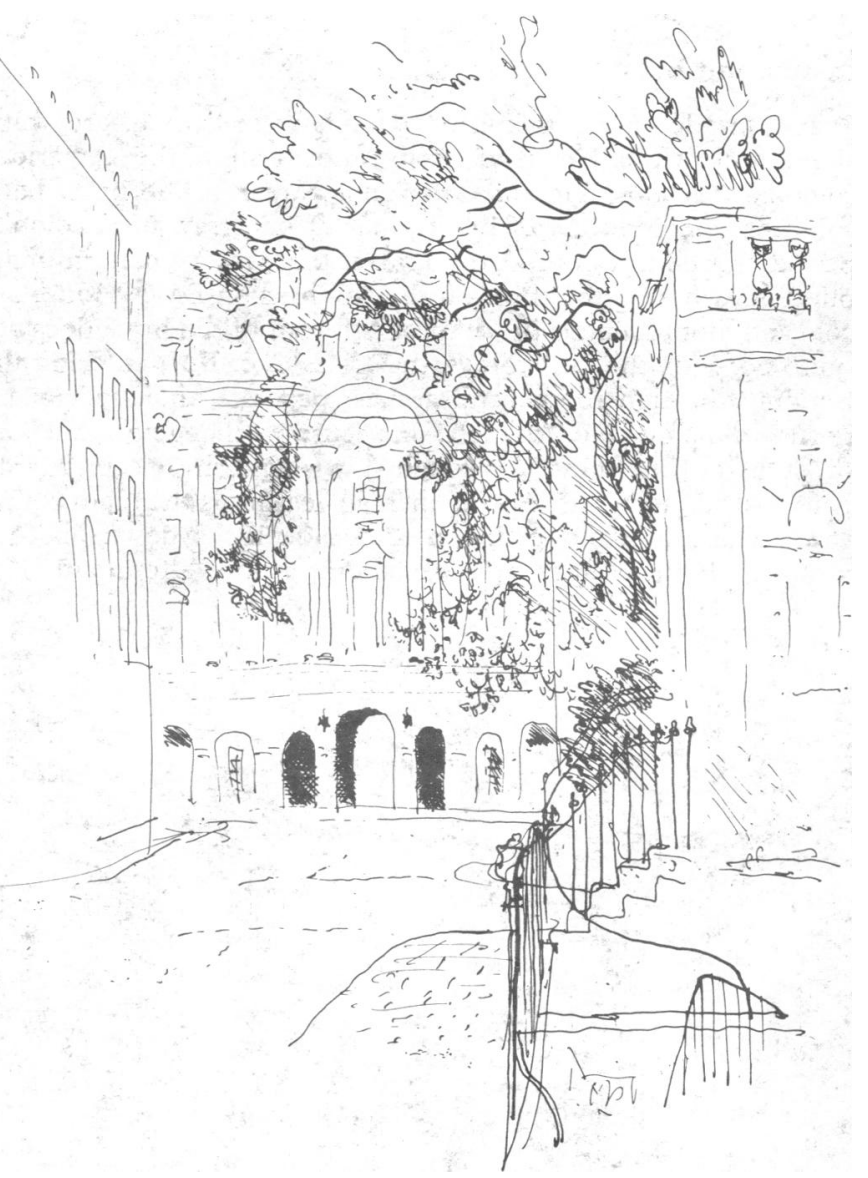

Some of David Gentleman's other sketches of BMA House appear as fillers in this issue. 